\title{
Impact of Different Priming Methods on Growth, Yield and Seed Quality Parameters in Cowpea (Vigna unguiculata L.)
}

\author{
Yeluri Bharath Chandu*, Pulivarthi Vineela, Arun Kumar Chaurasia, \\ Kandula Uma Maheswari and N. Bhavana Stella
}

${ }^{1}$ Department of Genetics and Plant Breeding, Naini Agricultural Institute, Sam Higginbottom University of Agriculture, Technology and Sciences, Prayagraj, U. P., India

${ }^{2}$ Director, State Institute for Management of Agriculture, Department of Agriculture, Govt. of. Uttar Pradesh, India

*Corresponding author

\section{A B S T R A C T}

\begin{tabular}{|c|}
\hline Keywords \\
\hline $\begin{array}{l}\text { Cowpea, Different } \\
\text { pre-sowing seed } \\
\text { treatments, Quality } \\
\text { parameters, Vigour } \\
\text { and seed yielding } \\
\text { attribute }\end{array}$ \\
\hline Article Info \\
\hline $\begin{array}{l}\text { Accepted: } \\
18 \text { November } 2020 \\
\text { Available Online: } \\
10 \text { December } 2020\end{array}$ \\
\hline
\end{tabular}

The experiment was conducted in post graduate Seed Testing Laboratory, Department of Genetics and Plant Breeding, Sam Higginbottom University of Agriculture, Technology and Sciences, Prayagraj (U.P.) during Kharif season 2019-2020, in order to standardize the suitable pre-sowing seed treatment of Cowpea (var). Pre-sowing seed treatments with control (Unprimed) were evaluated by screening 12 hour viz., $\mathrm{T}_{0}-$ Control, $\mathrm{T}_{1}-\mathrm{DH}_{2} \mathrm{O}, \mathrm{T}_{2}$ - $\mathrm{PEG}_{6000} @(2 \%), \mathrm{T}_{3}-$ Mannitol @ (2\%), T $4-\mathrm{GA}_{3} @(100 \mathrm{ppm}), \mathrm{T}_{5}-\mathrm{SA} @(100 \mathrm{ppm})$, $\mathrm{T}_{6}$ - IBA @ (100 ppm), T 7 - KCl @ (2\%), T $-\mathrm{KNO}_{3} @(2 \%), \mathrm{T}_{9}-\mathrm{CaCl}_{2} @(2 \%), \mathrm{T}_{10}-$ Curry leaf extract @(5\%), $\mathrm{T}_{11}$ - Moringa leaf extract @ (5\%), $\mathrm{T}_{12}$ - Neem leaf extract $@(5 \%)$. It was found that all the pre-sowing seed treatments showed significance difference with the control and in laboratory condition highest germination per cent, seedling length, seedling fresh weight, seedling dry weight, vigour indices were observed for $\mathrm{T}_{2}-\mathrm{PEG}_{6000}(2 \%)$. In field highest field emergence percentage observed in $\mathrm{T}_{5^{-}} \mathrm{SA}$ (100 ppm) and Plant height highest observed in $\mathrm{T}_{4}-\mathrm{GA}_{3} @(100 \mathrm{ppm})$, number of pods per plant, seed yield per plant, seed yield per plot, biological yield, harvest index was observed for $\mathrm{T}_{2}-\mathrm{PEG}_{6000} @(2 \%)$. Observed highest germination and yielding parameters in $\mathrm{PEG}_{6000}$ @ $(2 \%)$. Pre-sowing seed treatment with $\mathrm{PEG}_{6000}$ enhance germinability and seedling character, its simplicity and no requirement for expensive equipment and chemical could be used as a simple method for overcoming related to a poor germination and seedling establishment.

\section{Introduction}

Pulses are the important sources of proteins, vitamins and minerals and are popularly known as "Poor man's meat" and "rich man's vegetable", contribute significantly to the nutritional security of the country. Currently, we are in the mid-way of self-sustaining in pulses production as we are world leader in production, consumption and import as well. India import 2-3 million tons (MT) of pulses during 2010-11, causing huge hard foreign 
earning. By the 2050 we will able to sustain our production and we turned to net importer to net exporter for pulses if every things goes as per plan.

Cowpea (Vigna unguiculata L. Walp.) belongs to family Leguminaceae, an annual legume. It is a self-pollinated crop having chromosome no $2 n=22$. It is the most important pulse crop in the world for food as well as fodder. In India, cowpea is a premier pulse crop occupying 5.71 million ha and contributing 4.87 million tones to pulse basket. It accounts for $5 \%$ of the world pulses production. India is the largest producer, with about 5 million tons, accounting of about $60 \%$ of total world production. The nutrient composition of cowpea seed has protein (24.8\%), fat (1.90\%), fiber (6.3\%), carbohydrates $(63.6 \%)$ and minerals (Calcium, Sodium, Magnesium, Phosphorous and Iron) and Vitamins, viz., thiamine $(0.00074 \%)$, riboflavin $(0.00042 \%)$ and niacin $(0.00281 \%)$ (El-Adawy, 2002).

Cowpea as the most diverse of the cultivated subspecies and the wide distributed, is an important food legume and versatile crop (Sanginga et al., 2002). Forage yield of cowpea is the highest in sandy loam soils supplemented with suitable irrigation. Cowpea seed yield can be relatively high when grown in soils with low fertility. Moreover, high rates of nitrogen and excessive moisture are detrimental and can result in excessive vegetative growth, delayed maturity and pod shattering (Ali et al., 2004).

In India, it is cultivated mainly in Gujarat, West Bengal, Tamil Nadu, Andhra Pradesh, Kerala and Orissa. In Gujarat, it is mainly grownin Sabarkantha, Banaskantha, Mehasana, Patan, Ahemdabad, Kheda and Anand district and commonly known as "chowli" in this area. In India, the total area under beans cultivation is about 136 (000 ha) with the production 1373 (000 MT) (Anonymous, 2014-2015). Mostly, cowpea is grown in warm and kharif season in India and often cultivated as intercrop.

Cowpea is more remunerative with other crops with some saving of fertilizers for higher and profitable yield. It can fix atmospheric nitrogen in the soil by their symbiotic relationship with a specific soilbacteria (Rhizobium spp.). It requires very few inputs, as the plants root nodules are able to fix atmospheric nitrogen, making it a valuable crop for resource poor farmers and well-suited to intercropping with other crops. The whole plant is used as forage for animals, with its use as cattle feed likely responsible for its name.

Seed invigoration is a technique of seed enhancement it implies an improvement in seed vigour by any postharvest treatment resulting in improved germination, better field emergence and longer storability than un treated seeds which helps seedlings to grow in biotic and abiotic stress conditions (Ashraf and Foolad, 2005). Priming of seeds has shown to have beneficial effects on germination and emergence of many species (Brad ford, 1986). Pre- soaking of seeds causes hydration of membrane proteins and initiation of several processes (Bewley and Black, 1982)

\section{Materials and Methods}

The Research study was conducted at experimental research field, Department of Genetics and Plant Breeding, Naini Agriculture Institute, Sam Higginbottom University of Agriculture, Technology and Sciences, Prayagraj during kharif-2019. The experiment was carried out at Field Experimentation Centre of the Department of Genetics and Plant Breeding, Sam Higginbottom University of Agriculture, 
Technology \& Sciences. Prayagraj (UP) during Kharif-2019.

The source of seed material was obtained from Indian Institute of Pulse Research, Kanpur and the experiment was conducted in Randomized block design (R.B.D) with three replications in field followed by Completely Randomized Design (C.R.D) with four replications in lab and the variety used in this Experiment was Swarna (v-38). The data was collected on five randomly selected plants from each plot and measurement of different observations was recorded. The treatments were represented as T0 (Control), T1 (Distilled water), T2 ( PEG $\left._{6000} @ 2 \%\right), \mathrm{T} 3$ (Mannitol@2\%), T4 (GA @100 ppm), T5 (Salicylic acid@100 ppm), T6 (IBA@ 100 ppm), T7 ( $\mathrm{KCl} @ 2 \%) \mathrm{T} 8\left(\mathrm{KNO}_{3} @ 2 \%\right), \mathrm{T} 9$
( $\left.\mathrm{Cacl}_{2} @ 2 \%\right), \mathrm{T} 10$ (Curry Leaf Extract @5\%), T11(Moringa Leaf Extract @ 5\%), T12 (Neem Leaf Extract @ 5\%).

\section{Results and Discussion}

It is evident from the present investigation that priming treatments has significant effect on growth, quality and yield parameters in Cowpea. pre sowing seed treatment with T0 Control, T1- Distilled water, T2- PEG $_{6000}$ @2\%, T3- Mannitol @2\%, T4- GA 3 @100 ppm, T5 (Salicylic acid @ 100 ppm, T6- IBA @ 100 ppm, T7- KCl @ 2\%, T8- $\mathrm{KNO}_{3} @ 2 \%$, T9- $\mathrm{Cacl}_{2} @ 2 \%, \mathrm{~T} 10$ - Curry Leaf Extract @ 5\%, T11- Moringa Leaf Extract @ 5\%, T12Neem Leaf Extract @5\% have positive effect on Growth, Yield and Seed quality parameters (Table 1 and 2).

Table.1 Mean performance of cowpea for ten growths and yielding attribute

\begin{tabular}{|c|c|c|c|c|c|c|c|c|c|c|c|}
\hline S.No. & $\begin{array}{l}\text { Treat } \\
\text { ments }\end{array}$ & $\begin{array}{c}\text { Field } \\
\text { Emergence } \\
\text { percentage }\end{array}$ & $\begin{array}{c}\text { Days to } \\
50 \% \\
\text { Flowering }\end{array}$ & $\begin{array}{c}\text { Plant } \\
\text { height } \\
\text { (cm) }\end{array}$ & $\begin{array}{c}\text { Number } \\
\text { of } \\
\text { Branches } \\
\text { Per Plant }\end{array}$ & $\begin{array}{c}\text { Number } \\
\text { of Pods } \\
\text { Per } \\
\text { Plant }\end{array}$ & $\begin{array}{l}\text { Number } \\
\text { of Seeds } \\
\text { Per Pod }\end{array}$ & $\begin{array}{c}\text { Seed } \\
\text { yield per } \\
\text { plant (g) }\end{array}$ & $\begin{array}{c}\text { Seed } \\
\text { yield } \\
\text { per plot } \\
\text { (g) }\end{array}$ & $\begin{array}{c}\text { Biologic } \\
\text { al yield } \\
\text { (g) }\end{array}$ & $\begin{array}{c}\text { Harv } \\
\text { est } \\
\text { index }\end{array}$ \\
\hline 1 & $\mathbf{T}_{0}$ & 75.00 & 42 & 69.96 & 5.00 & 6.00 & 8.90 & 14.78 & 200.02 & 678.97 & 29.48 \\
\hline 2 & $T_{1}$ & 82.67 & 36 & 81.66 & 5.67 & 7.40 & 10.15 & 20.51 & 266.59 & 814.60 & 32.79 \\
\hline 3 & $\mathbf{T}_{2}$ & 88.33 & 34 & 87.08 & 8.00 & 14.00 & 13.13 & 27.12 & 515.28 & 1348.75 & 38.21 \\
\hline 4 & $\mathbf{T}_{3}$ & 79.00 & 38 & 83.96 & 6.00 & 10.60 & 12.33 & 19.23 & 250.03 & 786.20 & 31.84 \\
\hline 5 & $\mathbf{T}_{4}$ & 87.33 & 33 & 92.06 & 7.00 & 13.47 & 14.75 & 26.71 & 480.72 & 1290.15 & 37.35 \\
\hline 6 & $\mathbf{T}_{5}$ & 88.67 & 34 & 90.95 & 7.00 & 12.00 & 13.67 & 25.30 & 430.16 & 1183.92 & 36.28 \\
\hline 7 & $T_{6}$ & 81.33 & 37 & 73.37 & 6.00 & 8.00 & 11.76 & 16.11 & 209.39 & 692.93 & 30.18 \\
\hline 8 & $\mathbf{T}_{7}$ & 80.67 & 41 & 74.58 & 6.00 & 10.00 & 11.30 & 24.09 & 361.40 & 1016.86 & 35.73 \\
\hline 9 & $\mathbf{T}_{8}$ & 85.00 & 35 & 82.49 & 7.00 & 10.35 & 12.73 & 20.48 & 266.28 & 793.62 & 33.56 \\
\hline 10 & $T_{9}$ & 84.00 & 36 & 72.15 & 6.00 & 7.67 & 10.96 & 18.82 & 244.66 & 767.17 & 32.03 \\
\hline 11 & $\mathbf{T}_{10}$ & 78.33 & 38 & 84.54 & 7.00 & 6.69 & 9.75 & 23.51 & 352.70 & 1005.64 & 35.12 \\
\hline 12 & $T_{11}$ & 83.67 & 35 & 78.48 & 7.00 & 7.00 & 10.64 & 15.19 & 212.71 & 686.98 & 30.83 \\
\hline 13 & $\mathrm{~T}_{12}$ & 77.33 & 39 & 81.81 & 6.00 & 9.55 & 12.03 & 22.77 & 318.78 & 917.60 & 34.67 \\
\hline \multicolumn{2}{|c|}{ Grand Mean } & 82.41 & 36.77 & 81.01 & 6.44 & 9.44 & 11.70 & 21.13 & 316.06 & 921.80 & 33.70 \\
\hline \multicolumn{2}{|c|}{ F test } & $\mathrm{S}$ & $\mathrm{S}$ & $\mathrm{S}$ & $\mathrm{S}$ & $\mathrm{S}$ & $\mathrm{S}$ & $\mathrm{S}$ & $\mathrm{S}$ & $\mathrm{S}$ & $\mathrm{S}$ \\
\hline \multicolumn{2}{|c|}{ C.D. $(5 \%)$} & 5.02 & 4.67 & 4.86 & 2.38 & 1.37 & 1.40 & 4.75 & 72.48 & 210.92 & 2.28 \\
\hline \multicolumn{2}{|c|}{ SE(m) } & 2.13 & 1.94 & 2.01 & 0.82 & 0.47 & 0.48 & 1.63 & 24.83 & 72.26 & 0.78 \\
\hline \multicolumn{2}{|c|}{$\operatorname{SE}(d)$} & 3.01 & 2.75 & 2.84 & 1.15 & 0.66 & 0.68 & 2.30 & 35.12 & 102.20 & 1.10 \\
\hline \multicolumn{2}{|c|}{ C.V. } & 4.48 & 10.04 & 4.29 & 21.97 & 8.63 & 7.08 & 13.33 & 13.61 & 13.58 & 4.01 \\
\hline
\end{tabular}


Table.2 Mean performance of cowpea for eight seedling characters

\begin{tabular}{|c|c|c|c|c|c|c|c|c|c|}
\hline S.NO. & $\begin{array}{l}\text { Treat } \\
\text { ments }\end{array}$ & $\begin{array}{l}\text { Germin } \\
\text { ation } \\
\text { percenta } \\
\text { ge }\end{array}$ & $\begin{array}{c}\text { Root } \\
\text { Length } \\
\text { (cm) }\end{array}$ & $\begin{array}{l}\text { Shoot } \\
\text { Length } \\
\text { (cm) }\end{array}$ & $\begin{array}{l}\text { Seedling } \\
\text { Length } \\
\text { (cm) }\end{array}$ & $\begin{array}{c}\text { Fresh } \\
\text { Weight of } \\
\text { Seedling } \\
\text { (g) }\end{array}$ & $\begin{array}{c}\text { Dry } \\
\text { Weight of } \\
\text { Seedling } \\
\text { (g) }\end{array}$ & $\begin{array}{c}\text { Seed } \\
\text { Vigour } \\
\text { Index-I }\end{array}$ & $\begin{array}{c}\text { Seed } \\
\text { Vigour } \\
\text { Index-II }\end{array}$ \\
\hline 1 & $\mathbf{T}_{0}$ & 77.00 & 10.03 & 12.30 & 22.33 & 2.69 & 0.328 & 1721.38 & 25.17 \\
\hline 2 & $\mathbf{T}_{1}$ & 84.25 & 10.59 & 12.05 & 22.64 & 3.14 & 0.386 & 1912.19 & 32.50 \\
\hline 3 & $\mathbf{T}_{2}$ & 91.00 & 14.47 & 20.20 & 34.41 & 5.71 & 0.779 & 3128.82 & 70.77 \\
\hline 4 & $\mathbf{T}_{3}$ & 81.75 & 13.26 & 15.70 & 28.96 & 4.87 & 0.577 & 2373.31 & 47.12 \\
\hline 5 & $\mathbf{T}_{4}$ & 89.50 & 14.21 & 18.62 & 33.09 & 5.47 & 0.724 & 2962.47 & 64.54 \\
\hline 6 & $\mathbf{T}_{5}$ & 88.00 & 14.01 & 17.52 & 31.53 & 5.33 & 0.666 & 2771.94 & 58.62 \\
\hline 7 & $T_{6}$ & 84.50 & 12.98 & 13.20 & 26.18 & 4.45 & 0.503 & 2212.77 & 42.52 \\
\hline 8 & $\mathbf{T}_{7}$ & 78.25 & 13.26 & 14.40 & 27.66 & 4.69 & 0.547 & 2164.00 & 42.80 \\
\hline 9 & $\mathbf{T}_{8}$ & 87.00 & 13.51 & 16.10 & 29.61 & 5.04 & 0.605 & 2579.97 & 52.63 \\
\hline 10 & $\mathbf{T}_{9}$ & 86.00 & 11.63 & 12.60 & 24.23 & 3.74 & 0.414 & 2086.03 & 35.58 \\
\hline 11 & $T_{10}$ & 80.75 & 10.03 & 12.42 & 22.45 & 3.06 & 0.353 & 1815.19 & 28.51 \\
\hline 12 & $T_{11}$ & 85.25 & 11.03 & 12.25 & 23.28 & 3.31 & 0.395 & 1981.08 & 33.64 \\
\hline 13 & $\mathrm{~T}_{12}$ & 79.50 & 11.93 & 13.01 & 24.94 & 4.05 & 0.442 & 1981.97 & 35.13 \\
\hline \multicolumn{2}{|c|}{ Grand Mean } & 84.06 & 12.38 & 14.64 & 27.02 & 4.27 & 0.517 & 2283.93 & 43.81 \\
\hline \multicolumn{2}{|c|}{ F test } & $\mathbf{S}$ & $\mathbf{S}$ & $\mathbf{S}$ & $\mathbf{S}$ & $\mathbf{S}$ & $\mathbf{S}$ & $\mathbf{S}$ & $\mathbf{S}$ \\
\hline \multicolumn{2}{|c|}{ C.D. $(5 \%)$} & 2.95 & 2.59 & 3.43 & 4.19 & 0.44 & 0.12 & 376.59 & 10.25 \\
\hline \multicolumn{2}{|c|}{ SE(m) } & 1.03 & 0.90 & 1.20 & 1.46 & 0.15 & 0.04 & 131.65 & 3.58 \\
\hline \multicolumn{2}{|c|}{ SE(d) } & 1.46 & 1.28 & 1.69 & 2.07 & 0.22 & 0.06 & 186.18 & 5.07 \\
\hline \multicolumn{2}{|c|}{ C.V. } & 2.45 & 14.67 & 16.39 & 10.86 & 7.34 & 16.70 & 11.52 & 16.36 \\
\hline
\end{tabular}

In general, most of the treatment was found effective in increasing the yield attributes at all stages significantly as compared to control. In the growth, yield attributing parameters such as Plant Height, the maximum was recorded in T4-GA 3 @ 100 ppm (92.06cms) and it was followed by T5-Salicylic acid @ $100 \mathrm{ppm}(90.95 \mathrm{cms})$ and the lowest was observed in T0-control, $(69.96 \mathrm{cms})$.

In Days to $50 \%$ Flowering the maximum was recorded in treatment $\mathrm{T} 0$ (control) and it was followed by treatment $\mathrm{T} 7(\mathrm{KCl} @ 2 \%)$ and the minimum Days to $50 \%$ flowering was recorded in $\mathrm{T} 2\left(\mathrm{PEG}_{6000} @ 2 \%\right)$. However in No. of Pods/plant, Seed yield/plant (gm), Seed yield/plot (gm),Biological yield, Harvest index the maximum was recorded in T2$\mathrm{PEG}_{6000} @ 2 \%$ and it was followed by $\mathrm{T}_{4}-\mathrm{GA}_{3}$ @ 100 ppm with the least recorded in T0 (control). In Germination the maximum was recorded in $\mathrm{T}_{2}-\mathrm{PEG}_{6000} @ 2 \%(91.00 \%)$ and it was followed by $\mathrm{T}_{4}-\mathrm{GA}_{3} @ 100 \mathrm{ppm}$
$(89.50 \%)$. In seedling length the maximum was recorded in T2-PEG 6000 @ 2\% (34.41cm) and it was followed by $\mathrm{T}_{4}-\mathrm{GA}_{3} @ 100$ $\operatorname{ppm}(33.09 \mathrm{~cm})$. In fresh weight and Dry weight of seedlings the maximum was recorded in $\mathrm{T} 2-\mathrm{PEG}_{6000} @ 2 \%(5.71 \mathrm{~g} \& 0.77 \mathrm{~g}$ ) respectively. In seed vigour index-I and seed vigour index-II the maximum was recorded in T2-PEG $6000 \quad @ \quad 2 \% \quad(3128.82 \quad \& \quad 70.77)$ respectively. Based on the present investigation it is concluded that Seed priming with PEG $_{6000}(2 \%)$ showed best results for all field parameters and lab parameters followed by $\mathrm{GA}_{3}(100 \mathrm{ppm})$.

From the present investigation it is concluded that the Pre-sowing seed treatment increases the germinability and vigour of cowpea seeds, significantly in both lab and field condition. Pre-sowing treatment with polyethylene glycol (2\%) followed by Gibberellic Acid (100 ppm), Salicylic Acid (100 ppm), Potassium nitrate(2\%), Potassium Chloride 
(2\%) and Mannitol (2\%) significantly increased the seed quality parameters of cowpea. Pre-sowing seed treatment with $\mathrm{PEG}_{6000}$ and $\mathrm{GA}_{3}$ showed maximum increase in germinability and vigour of cowpea seeds and found to be lowest in control seeds. Priming of the cowpea seeds for $12 \mathrm{hrs,} \mathrm{in}$ which $\mathrm{PEG}_{6000}$ give best result to enhanced germinability, vigour and quality parameters. These conclusions are based on the results of six months investigation and therefore further investigation is needed to arrive at valid recommendations. The Pre-sowing seed treatment with $\mathrm{PEG}_{6000}$ are eco-friendly and economic in use.

\section{References}

Aghbolaghi, M. A. Md. Sedghi, (2014). The effect of osmo and hormone priming on germination and seed reserve utilization of millet seeds under drought stress. Journal of Stress Physiology \& Biochemistry, 10(1): 214-221.

Ali, U. A.,Tareen, S., Md. JavedAli., Ijaz, T. and Md. Naveed., (2012). Effects of seed priming on the antioxidant enzymes activity of mungbean (Vigna radiata) seedlings. Pakistan Journal of Nutrition, 11(2):140.

Amanpour-Balaneji, B., and Sedghi, M. (2012). Effect of aging and priming on physiological and biochemical traits of common bean (Phaseolus vulgaris L.) Notulae Scientica Biologicae. 4 (2): 95- 100

Anburani A, Shakila A. (2010). Influence of seed treatment on the enhancement of germination and seedling vigour of papaya. Acta Horticulturae. 851:295298.

Anonymous (2014-15). Indian Horticulture Database - 2014. NHB, Ministry of Agriculture, Government of India.

Anosheh HP, Sadeghi H and Emam Y.
(2011). Chemical priming with urea and $\mathrm{KNO}_{3}$ enhances maize hybrids (Zea mays L.) seed viability under abiotic stress. Journal of Crop Science and Biotechnology 14: 289-295.

Ansari O, Sharif-Zadeh F. (2012). Does Gibberelic acid (GA), Salicylic acid (SA) and Ascorbic acid (ASc) improve Mountain Rye (Secale montanum) seeds Germination and Seedlings Growth under Cold Stress?. Int. Res. J. Appli. Basic Sci. 3 (8):1651-1657.

Chavan, N. G., Bhujbal, G. B AND Manjare, M. R., (2014).Effect of Seed Priming on Field Performance and Seed Yield of Soybean [Glycine max (L.)Merill] Varieties. Thebioscan, 9(1): 111-114.

Chavoshinasab, S., SharifZadeh, F. and Abbasi, A. (2010). The effect of postpriming treatments on seed longevity of Viciada sycrapa and V. ervillia primed seeds. The requirements for degree of Master of Science (M. Sc.) in Seed Science and Technology.

Chen K and Arora R. (2011). Dynamics of the antioxidant system during seed osmopriming, post-priming germination, and seedling establishment in spinach (Spinacia oleracea). Plant Science 180: 212-220.

Faijunnahar, M., Baque, A., Habib, M.A., and Hossain, H.M.M.T. (2017). Polyethylene glycol (PEG) induced changes in germination, seedling growth and water relation behavior of wheat (Triticum aestivum L.) genotypes. Universal Journal of Plant Science. 5 (4): 49-57.

Golmohammadzadeh, S., Zaefarian, F. and Rezvani, M. (2014). Investigation of different priming techniques on seed germination of papaver species. International Journal of Biosciences 4(3): 1-9.

Khadraji, A., Mouradi, M., Houasli, C., Qaddoury, A., and Ghoulam, C. 
(2017). Growth and antioxidant responses during early growth of winter and spring chickpea (Cicer arietinum) under water deficit as affected by osmopriming. Seed Science and Technology. 45 (1): 1-14.

Umair, A., Safdar Ali., Muhammad Sarwar., Kashif Bashir., Muhammad Javed Tareen and Muhammad Asghar Malik., (2015). Assessment of Some Priming Techniques in Mungbean (Vigna radiata: a Green House Study. Pakistan Journal of Agricultural Research, 26(4): 265-274.

Varier A, Vari AK and Dadlani M. (2010). The subcellular basis of seed priming. Current Science 99: 450-456.

Yacoubi R, Job C, Belghazi M, Chaibi W and Job D. (2013). Proteomic analysis of the enhancement of seed vigour in osmoprimed alfalfa seeds germinated under salinity stress. Seed Science Research 23: 99-110.

Yari L, Aghaalikani $M$ and Khazaei $F$. (2010). Effect of seed priming duration and temperature on seed germination behaviour of bread wheat (Triticum aestivum L.). ARPN Journal of Agricultural and Biological Science 5: 1.

Zhang F, Yu J, Johnston CR, Wang Y, Zhu K, Lu F, Zhang Z and Zou J. (2015). Seed priming with polyethylene glycol induces physiological changes in sorghum (Sorghum bicolor L. Moench) seedlings under suboptimal soil moisture environments. PLoS One 10: e0140620.

\section{How to cite this article:}

Yeluri Bharath Chandu, PulivarthiVineela, Arun Kumar Chaurasia, KandulaUma Maheswari and Bhavana Stella, N. 2020. Impact of Different Priming Methods on Growth, Yield and Seed Quality Parameters in Cowpea (Vigna unguiculata L.). Int.J.Curr.Microbiol.App.Sci. 9(12): 2691-2696. doi: https://doi.org/10.20546/ijcmas.2020.912.318 